\title{
Approaching an Abstract Cinematic Form: The Tree of Life by Terrence Malick
}

\author{
Christos Dermentzopoulos \\ Ioannina University, Ioannina, Greece
}

\author{
Thanassis Vassiliou \\ Aix-Marseille University, Aix-en-Provence, France
}

\begin{abstract}
One of the most important tools in film analysis is "segmentation", as defined by the major film theorist Christian Metz, with the help of the "great syntagmatic" (Grande Syntagmatique); an array, which will guarantee the classification of any kind of shot in any kind of film and its consequent decoding. The division into sections allowed a clinical approach of high validity, highlighting the hidden rhymes, the power of repetition, the underlying pulses of the film, "decoding", in a way, their soul; in essence their meaning. However, by the mid-1970s, the semiotics of cinema was considered outdated and unrealistic, mainly because it failed to solve a problem to which it was believed that it held the key to guarantee the "translation" of any abstract cinematic form. In this text, we attempt to explore what semiotics can do today and how far "segmentation" can take us in the face of a particularly "opaque" film, which is made of fragments of impressions, disparate elements and contrasts, such as The Tree of Life (2011) by Terrence Malick.
\end{abstract}

Keywords: Metz, segmentation, Grand Syntagmatique, narration, editing

\section{Introduction}

The connection between cinema and narrative was established, somewhat unexpectedly, at the beginning of cinematic history by juxtaposing a technique of representation with the art of narration. However, it was not long before "this constituted a social event, an event of civilization", as Christian Metz (2003) admits.

The first creators of the "cinematic language" (a deeply problematic term that we will barely touch upon here) such as G. Melies, E. Porter, G. A. Smith, or D. W. Griffith, were mainly interested in the potential of films as a narrative medium. It is their interest in solving certain narrative issues that finally led them to invent a considerably large number of structural cinematic principles, which would in turn establish the various cinematic systems that we refer to as styles.

\section{Semiology and Semiotics}

It was inevitable that the prevalence of semiology in France from the mid-60s and for about a decade, based on the ideas of structuralism which preceded it, would also define cinematic analysis and theory by offering a new approach to films. The cinematic narrative structures which were invented by the great directors of the early years and developed by their successors, such as Sergei Eisenstein, Abel Gance, Fritz Lang, Howard Hawks, Dziga Vertov, and others, began to be "categorized", "classified" and, in the end, "translated"

Christos Dermentzopoulos, associate professor, Department of Fine Arts and Sciences of Art, Ioannina University.

Thanassis Vassiliou, adjunct professor, Département of Cinéma, Aix-Marseille University. 
through certain semiological "patterns" which guaranteed a more concrete, "tangible" analysis. Guy Gauthier (1991) notes:

Deep inside, though not openly admitted, there was a common haunting among researchers and others. They felt that (through semiology) everything can be controlled. There was nothing, no book, no film, not even an opinion, which could not be deconstructed and processed by some computer program, which could in turn re-construct everything to its liking. (p. 106)

The way in which every director chooses to tell their story is for cinematic theory and criticism an undoubtedly interesting prism through which films would be "deciphered" and all their secrets revealed. In other words, with the contribution of semiology, film theory becomes akin to scientific analysis. Semiologists believe that whereas viewers think they are entering the film through the signifier, semiologists know they are entering through the signified. This belief clearly reflects the scientific concerns of the semiologists, who are aware that equating cinema with language and the magic of the signifier could prove exceptionally unfortunate. Every time an image would be bestowed the characteristics of a word, film theory would risk getting lost in a maze of contradiction, as the relationship between the signifier and the signified has always been one of convention, either through abstraction or intention. "If I tell you the word 'table', each of you will imagine a different table, while if I show you a filmed table, you will all see the same table" (personal communication, February, 3, 2004), Marguerite Duras famously said, eloquently demonstrating the difference in dynamics between language and cinematic image. As Jean Mitry (1963) noted:

A film is, before and above all else, images, and indeed, images of things ... These images, organized according to the chosen narrative in a system of signs and symbols, become symbols or can even become something more. They are not signs like words, but are, first and foremost, objects, a concrete reality. This is the only way in which we can say that cinema is a language. It becomes language on condition that, before all else, it is representation. It is a language in the second degree, if you will. (p. 56)

\section{Christian Metz}

The juxtaposition between film theory and semiology, which is before and above all else realistic, specific, and objective, produced through a clinical approach the most interesting cinematic analyses, many of which even evolved into theories. The first to approach film theory with a modern scientific attitude was Christian Metz. "He wasn't looking for truth", says Gauthier (1991), "he moved on. He only cared about what was spoiled, corrupt" (p. 148).

This important thinker aimed at uncovering the "fundamental figures of communicating all information" (Metz, 2003, p. 145), based on the notion that cinema might appear to be a language, but literary analysis ought to approach it as a dialect. Metz adopted the tools of linguistics, starting rigorous research into segments and attempting to discover the codes according to which these segments function. His scheme, which is called the Grande Syntagmatique, constitutes an important theoretical "gadget" in film analysis and semiology's approach towards understanding films. Metz (2003) claimed that, with the Grande Syntagmatique, "what needs to be understood is the fact that films can be understood" (p. 145).

Film analysis, which preexisted both semiology and structuralism, had always and will always use three basic types of "tools":

(1) Description. In a narrative film everything can be described (decoupage, segmentation, images etc.). Hence, everything can be an item of study, by "highlighting" or "underlining" it through description. In other 
words, "there is no grammar in cinema, only rhetoric" (Mitry, 1987, p. 145).

(2) Subjective approach. Which of the elements originally identified by the analyst can be the objects of a detailed study with a view to "translating" the film into a satisfying written version? Some examples include structural highlighting, frame analysis, sound track analysis, cultural references, camera movement, direction characterization etc..

(3) Archive materials. It involves the use of records, before and after the completion of the film, which provide information about it, without necessarily being part of the film (interviews, texts, script changes, etc.).

Film semiology naturally contributed to the evolution of the first tool of film analysis, namely description. By using the unquestionable fact that the shot is the minimal unit and the crux of the narrative, Metz applies to cinema one of the fundamental principles of semiology, borrowing from Louis Hjelmslev (1963) the accentuation of an important distinction: the one between units and system, which will eventually help us discover the existence of a code. The discovery of a code for any information communicating system, and for film in particular, is fundamental to the scientific approach proposed by film semiology. As noted by Jacques Aumont, Alain Bergala, Michel Marie, and Marc Vernet (2004):

Codes are not truly formal models, as they often are in logic, but rather units aspiring to formalization. Their homogeneity is not of a sensorial or material nature but is instead on the order of the logic of coherence, possessing anexplanatory and enlightening potential. A code is understood in semiotics as a field of commutations. Within this field, the variations of the signifier correspond to variations of the signified and a certain number of units take their meaning only in relation to other member units. (p. 160)

This important antithesis between a cinematic unit, which is - originally - the shot, and a system, which is - eventually — the film, decisively contributed to the creation of the Grande Syntagmatique.

\section{Segmentation}

As early as 1961, the French magazine L'Avant-Scène Cinéma, had begun publishing the decoupage of famous films, thus exhibiting a tendency towards a "structural translation", by counting shots, shot durations, sizes, image-sound relationships, types of continuity, etc.. As a result, we could have an initial assessment of a film just by the number of shots it counted. With the average number of shots at 400 to 600 for a 90 -minute film, an informed viewer could immediately understand the "structural type" of Eisenstein's October (1928), which counted 3,225 shots, or Marguerite Duras' India Song (1975), which counted 73.

Segmentation, which is the evolution of the theoretical concerns behind these calculations, was the major point of interest for C. Metz. The modernism of the 1960s with its consecutive "new waves" in almost every country with a respectable film industry, complicates narrative constants, and film structure is transformed for the analyst who is accustomed to "academic" cinematic patterns, into a field wide open for interpretation. C. Metz focuses his interest on the proposition of a concrete code which could apply to any cinematic unit, thus defining their differences in a clear and convincing way. He continues the theoretical considerations of his predecessors André Malraux, Béla Balazs, Edgar Morin, and Jean Mitry, whose views converged on the importance of editing as the fundamental process around which cinema can be organized as discourse. With the Grande Syntagmatique, Metz (2003) divides cinematic units, named "syntagms" into eight categories, which can emerge as an "edited result" (pp. 121-145).

(1) The autonomous shot - a shot that constitutes a unit in itself (establishing shot or insert).

(2) The parallel syntagm. It consists of units which are juxtaposed through editing and do not have a 
temporal or spatial relation (synchronicity or proximity), but mainly a symbolic one (a montage of motifs, like shots of rich people - shots of poor people, shots of calm — shots of tension, shots of the city - shots of the countryside, etc.).

(3) The bracketing syntagm. It consists of units with no temporal relation which presents "representative examples of the same reality", for example, shots or scenes of life in a city which are not temporally related, but give a clear impression of life in this particular city.

(4) The descriptive syntagm. It consists of descriptive shots which are temporally linked and relate to the same space (for example, consecutive shots of a landscape) or action (consecutive shots of a shepherd's walk: shot of the shepherd - shot of the dog — shot of the herd, etc.).

(5) The alternating syntagm. It is also known as crosscutting and links two simultaneous actions which are usually connected. It is one of the most classic action units, the most prominent example being the alternation between the hunter and the hunted, who occupy the same space in close temporal proximity.

(6) The scene. A series of shots imply a temporal continuity. The signified is "fragmented" (into shots) while the signifier (the presented event) is understood as unfolding without "glitches" (hence, the term "continuity editing" in these instances).

(7) The episodic sequence. It consists of short shots which constitute abbreviated pieces of a larger narrative unit.

(8) The ordinary sequence. This is a series of shots which compose a complicated temporal development, discontinuous but homogeneous. Like in the scene, the signified is "fragmented", but in this syntagm the alternation of shots allows us to be taken to moments of action, whereas details of no apparent interest and dead time are excised (Stam, 2006, pp. 155-156; Stam, Burgoyne, Flitterman-Lewis, 1992, pp. 40-48).

\section{Semiotics Today}

Almost half a century later, structural film criticism continues to provide us with excellent analyses and even theoretical propositions. For instance, the three types of editing (continuity, discourse, correspondence), proposed by Vincent Amiel (2001), exemplify a categorization of editing which clearly draws its ideas from the study of the Grande Syntagmatique. On the other hand, William Guynn (2001) acknowledges the use of Metz's table in his attempt to analyze a large number of documentaries from a semiological standpoint, with a view to approaching cinematic discourse with reality through reality itself. Besides, one of the main criticisms of Metz's proposition was its bias towards the mainstream narrative film and the marginalization of other genres, such as avant-garde and documentary (Stam, 2006, p. 158). However, when cinema abandons the action-image or movement-image and turns its focus on the temporal identity of its images towards a cinema of time-image, as Deleuze suggests, the Grande Syntagmatique appears incapable of suggesting anything truly ground-breaking for film analysis. The modernism of neo-realism and, later, of "Nouvelle Vague" might have driven Metz to the formulation of the Grande Syntagmatique, but editing quickly lost interest both in classical narrative and the construction of a cinematic discourse. In other words, it stopped being dependent on an "external" theoretical basis. Gradually, form and style became more important than content. Films allowed editing to impose its rhythm "as is" and sensation to exceed representation.

In this way, editing is elevated from a tool of narration or discourse to an autonomous process, which asserts itself simply because it exists, as a pulse, as a rift between durations. Time is no longer an important feature of cinema. Time becomes the object of cinema. But can we discuss editing the way the term is widely 
used, as a "writing" tool, when it is not a construction fixed in advance? Can we discuss editing when there is essentially no decoupage and several directors, like Robert Bresson, view the filming experience as the "art of the encounter"? Can we discuss editing when randomness becomes a creative condition and intent plays no part in this exploration?

In these cases of "modern" cinema, the script is discovered and revealed during editing. It no longer defines a succession, a continuity, but it allows sensation to permeate the stitching of the shots, to take residence in the gaps between them, communicating another dimension of "representation". In films where duration is offered as experience and the alternation of shots as pulse, identifying them is no longer important. What is important is the discovery of the hidden connections formed among the various duration "blocks".

The nature of rhythm changes. It does not depend on the ratio of shots to duration, it is no longer measurable, becoming an "indeterminate constant" as a result of an "architecture of tension" (Amiel, 2001, p. 82). Tarkovsky's famous phrase about the intensity of time running through the shots indicates the drastic stylistic transformation of editing in particular, and of structural cinematic composition in general.

As cinema has constantly been searching for a meta-language since the $1960 \mathrm{~s}$, going from modernism to post-modernism, to a sense of satiety and back to a "new modernism which should first and foremost be postmodernism", according to De Duve (1998), the rejuvenation of structural cinematic principles has always been its main object of interest. From Godard to Angelopoulos, from Makavejev and Marker to Akerman, Wiseman, and WANG Bing, from Carax, Van Sant or Bella Tarr to Haneke and JIA Zhang-ke, innovative, ground-breaking cinema has always measured itself against different types of editing, which usually disregarded "highlighting the action". The classic distinction between a narrative and an experiential action model remained strong, despite the subversion of boundaries and genres in the postmodern era.

\section{The Case of Terrence Malick}

From this point of view, the cinema of Terrence Malick keeps distancing itself from all narrative concerns, as from film to film and through time periods it proposes a rather opaque and unconventional idiom. His recent film The Tree of Life (2011) (Palme d' Or, Cannes Festival, 2011) is one of the most alluring examples of this constant exploration.

Malick's cinema, by completely abandoning the constants of classical narrative, explores a fascinating balance between the narrated story and the use of non-narrative cinematic means. In other words, Malick's narrative, while arising from its negation, manages not only to survive, but also to radically rejuvenate itself. Since everything in The Tree of Life relies on this discourse, it is one of the most characteristic examples of the American creator's exploration. Brad Pitt, the film's protagonist and producer, speaks of a film "between randomness and perfection”. Alexandre Desplat, the film's composer, speaks of an unprecedented experience, as he had never been asked to score a film without having seen edited material (even Miles Davis improvised the score to Louie Malle's Elevator to the Gallows while watching an edited copy). Mark Yoshikawa, head of the team of five editors, speaks of Malick's concern that the viewer should never feel "the director's hand", as he calls it, "behind the images", and Emannuel Lubezki, the film's cinematographer, speaks of the instinctive, but also predetermined nature of an unforgettable shoot (Benghin, 2011).

How can modern film analysis and theory approach such a film through the lens of the Grande Syntagmatique? How helpful can structural highlighting and shot categorization be when applied to this post-narrative language? If Metz aimed to isolate the basic syntagmatic forms of narrative cinema and define 
cinema as a narrative language in response to the notorious vagueness of cinematic terms (Stam, 2006, p. 154), how can this perspective contribute to the analysis of Malick's film?

In his review in Cahiers du Cinéma, Cyril Benghin (2011) writes:

The details of direction in The Tree of Life are intrinsic to the complexity created by its structure, which is spread over five, more or less, connected parts. What story does the film tell? The death of a son; years later, the melancholy of Jack, one of his brothers; the birth of the universe; the elliptical fragments of a Texan childhood around a strict father and a mother as beautiful as an icon; the unexpected encounter of the living and the dead on the shores of a mystical coast. (p. 13)

The French critic clearly associates the style of the direction with the nature of the structure which supports the film. So do the director's collaborators. Although structure is clear and indisputable, any attempt at narrative segmentation is rendered null. Through most of the film, editing does not depend on the concept of continuity, parallel, or counterpoint, since its raw materials are shots which are basically products of freedom, serendipity and unpredictability. Lubezki (2011) notes:

In a film like this, you don't have to focus on continuity... We moved through space according to what we were looking for: the forbidden, the joyous, the mysteries. It all depended on the feeling... which Malick gave us in the form of notes every morning before shooting began... it was like fishing: Each (of the camera operators) was trying to catch the best fish. (p.17)

It is quite obvious that the lack of decoupage makes it impossible for the editor to use the syntagmatic types Metz suggested, even if he often wants to. Although Malick starts from the idea of five parts, he often "pierces" them with shots from other parts, thus breaking the confines that would guarantee a robust structure. The same happens from scene to scene and from shot to shot. Moments which are interrupted before they even begin and shots which are not given enough time to communicate their information to the viewer alternate with bizarre continuity cuts and drastic shifts in lenses and angles, at a pace sometimes lazy and other times frenzied, creating a visual poem of light and physicality, which stubbornly refuses to chart a specific course according to Metz's Grande Syntagmatique. It is of absolutely no use to re-construct the film by naming certain filmic lengths "scenes", "alternating syntagms", or "episodic sequences". There is no point in highlighting the boundaries among the parts. The editing of The Tree of Life negates any such attempt and emphasizes a story whose protagonist is none other than the magic of physical movement, natural light and the freedom of the performances.

\section{Conclusion}

The Grande Syntagmatique appears irrelevant before this cinematic experience for another important reason; it never had anything to offer on the relation between sound and image. The protagonists' voice-overs, which "embrace" the images and make them "theirs", the music themes which enter and exit unexpectedly, the magic of natural sounds, even silence, drastically change the visual result, adding another insurmountable problem to the segmentation posited by the Grande Syntagmatique. The narrative units are not defined by their "syntagmatic" character, but on the contrary, by the flowing force the editing bestows on them. In this way, narrative units stop being "units", but do not stop being "narrative". However, let us refrain from misguided parallels; this editing bears no relation to that of Eisenstein or Godard. It might bring to mind their expressive confusion, but it is actually disinterested in both the visual excess of a cubistic representation and the expressive tension of a fast pace. In The Tree of Life, the editing constantly selects and connects, it separates 
and juxtaposes, towards one goal; a sense of flow. It poses the question: If we deny continuity and linearity, how can we communicate a sense of smooth, uninterrupted flow? As a result, the film questions narrative constants with no intention to polemicize, like the experimental cinema, but with an unrestrained desire to revitalize. In this case, it turns out that the Grande Syntagmatique has absolutely nothing to offer.

\section{References}

Amiel, V. (2001). Esthétique du montage (Aesthetics of editing). Paris: Nathan.

Aumont, J., Bergala, A., Marie, M., \& Vernet, M. (2004). Aesthetics of film. Austin: University of Texas Press.

Beghin C. (2011). A l'Origine (At the origin). Cahiers du Cinéma, 668, 12-14.

De Duve, T. (1998). Kant after duchamp. An October book. Cambridge: MIT Press.

Gauthier, G. (1991). Christian Metz à la trace and Jean Mitry: Un Géant (Christian Metz on the trail and Jean Mitry: A Giant). CinémAction, 60.

Green, S., Pohland, B., Pitt, B., Gardner, D., \& Hill, G. (Producer), \& Malick, T. (Director). (2011). The tree of life [Motion Picture]. U.S.A.: Fox Entertainment.

Guynn, W. (2001). Un Cinéma de Non-Fiction (A non-fiction cinema). Aix-en-Provence: Publications de l'Université de Provenc. Hjelmslev, L. (1963). Prolégomènes à une théorie du langage (Prolegomena to a theory of language). Paris: Minuit. Lubezki, E. (2011). Interview. Cahiers du Cinéma, 668, 16-17.

Metz, C. (2003). Essais sur la signification au cinéma (Essays about significance on cinema). Paris: Klincksieck.

Mitry, J. (1963). Esthétique et Psychologie du Cinéma, t1 (Aesthetics and psychology of cinema). Paris: Éditions Universitaires.

Mitry, J. (1987). La sémiologie en question (Questioning semiology). Paris: Les Éditions du Cerf.

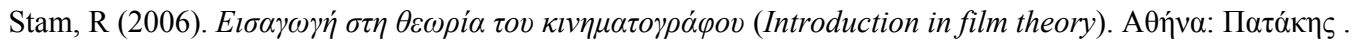

Stam, R., Burgoyne, R., \& Flitterman-Lewis, S. (1992). New vocabularies in film semiotics. London and New York: Routledge. 